\title{
Giant Cell Interstitial Pneumonia in a 15-year-old Boy
}

\author{
Tomoyuki Kakugawa, Hiroshi Mukae, Towako Nagata, Hiroshi IshiI, Hideyuki KaIda, \\ Tomayoshi Hayashi*, Takashi Suematsu**, Jun-ichi Kadota*** and Shigeru Kohno
}

\begin{abstract}
Giant cell interstitial pneumonia (GIP) is a very uncommon respiratory disease. We report a juvenile patient with GIP aged 15 years. Although he has a negative past history of direct exposure to hard metals, we could not exclude possible exposure in very small amounts through his parents. Microscopic examination of lung biopsy specimen obtained by video-assisted thoracoscopy revealed marked cellular interstitial infiltrates and prominent intraalveolar macrophages as well as giant cells showing cellular cannibalism. Analysis of the biopsied lung tissue for cobalt and tungsten was negative. Clinical symptoms, laboratory, and radiological findings improved markedly after treatment with corticosteroids. To our knowledge, only eleven cases of GIP have been reported in Japan. Although possible exposure to hard metals was identified in 9 of the 11 reported cases, there is no clear dose-dependent relationship with onset and prognosis. The average age at onset was $46.2 \pm 15.0$ years. Our patient is the youngest case of GIP reported in the world.
\end{abstract}

(Internal Medicine 41: 1007-1012, 2002)

Key words: juvenile onset, hard metal

\section{Introduction}

In 1968, Liebow and Smith presented a classification of chronic interstitial pneumonia that included usual interstitial pneumonia (UIP), desquamative interstitial pneumonia (DIP), bronchiolitis obliterans interstitial pneumonia (BIP), and giant-cell interstitial pneumonia (GIP) (1). GIP, which is considered as the most unusual form, is characterized by a prominent lymphoplasmacytic interstitial infiltration with numerous bizarre giant cells in alveoli. The multinucleated giant cells are actively phagocytic, frequently engulfing neutrophils, pneumocytes, and macrophages. Since this description, only sporadic case reports of GIP have been published. Recent studies suggest that the majority of cases of GIP are caused by exposure to cobalt or tungsten carbide as components of hard metals $(2,3)$. However, the mechanism (s) by which exposure to hard metal causes GIP is unknown. We report a case of juvenile-onset GIP in whom no clear history of exposure to hard metals was evident.

\section{Case Report}

A 15-year-old Japanese male, a junior high school student, was referred to our hospital in March 2001 because of twomonth history of cough and progressive exertional dyspnea. $\mathrm{He}$ had been diagnosed as partial growth hormone deficiency at the age of 12 , and had been treated with somatropin. There was no evidence of exposure to hard metals during normal daily life. His parents worked for a ship manufacturing plant for over 20 years, and were responsible for grinding and sanding hard metal fortified components of ships. However, no one in his family showed abnormalities on their chest radiographs and he had never been to this plant.

On admission, his height was $152 \mathrm{~cm}$ and weight was 45 $\mathrm{kg}$. Body temperature was normal. Physical examination revealed cervical, supraclavicular, axial and inguinal lymphadenopathies. No fingernail clubbing was seen. Fine crackles were audible on the lower aspects of both lungs. Arterial blood gas analysis at room air revealed $\mathrm{pH} 7.41, \mathrm{PaO}_{2} 87$ torr and $\mathrm{PaCO}_{2}$ 35 torr. The white blood cell count was $8,700 / \mathrm{mm}^{3}$ with $78 \%$ neutrophils, $16 \%$ lymphocytes, $2 \%$ monocytes, $3 \%$ eosinophils, and $1 \%$ basophils. Erythrocyte sedimentation rate and C-reactive protein were mildly elevated $(43 \mathrm{~mm} / \mathrm{h}$ and $0.19 \mathrm{mg} / \mathrm{dl}$, respectively). Levels of lactate dehydrogenase activity and immunoglobulin $\mathrm{G}$ were mildly elevated (463 IU/l and 2,280 $\mathrm{mg} / \mathrm{dl}$, respectively). Serum KL-6, surfactant protein (SP)-D and SP-A levels were also elevated $(895 \mathrm{U} / \mathrm{ml}, 211 \mathrm{ng} / \mathrm{ml}$, and $320 \mathrm{ng} / \mathrm{ml}$, respectively). Anti-nuclear antibody and anti-single strand deoxyribonucleic acid antibody were positive. Anti-ribonucleoprotein antibody and anti-double-strand DNA antibody were on the upper limit of the normal range. Antibodies

From the Second Department of Internal Medicine, Nagasaki University School of Medicine, Nagasaki, *the Department of Pathology, Nagasaki University Hospital, Nagasaki, **the Central Electron Microscopy Laboratory, Nagasaki University School of Medicine, Nagasaki and ***the Second Department of Internal Medicine, Oita Medical University, Oita

Received for publication April 5, 2002; Accepted for publication July 9, 2002

Reprint requests should be addressed to Dr. Hiroshi Mukae, the Second Department of Internal Medicine, Nagasaki University School of Medicine, 1-7-1 Sakamoto, Nagasaki 852-8501 
against several kinds of viruses including measles were all within the normal range. Lymphocyte stimulation tests to drugs administered before admission including somatropin were all negative. Pulmonary function tests demonstrated the following restrictive ventilatory defect and severe diffusion impairment; \%VC 47\%, \%DLCO 23\%, FEV1\% 91.4\%. Chest roentgenogram on admission revealed bilateral micronodular infiltrates in both lower lung fields (Fig. 1). Chest high resolution computed tomographic (HRCT) scans revealed diffuse groundglass opacities in both lungs with basilar predominance, and enlarged mediastinal lymph nodes (Fig. 2). Lung specimens obtained by TBLB showed widened alveolar septa by mild fibrosis and inflammatory cell infiltration, exaggerated hyperplastic reaction of type II pneumocytes. Examination of bronchoalveolar lavage (BAL) fluid showed elevated total cell count $\left(8.72 \times 10^{5} \mathrm{cells} / \mathrm{ml}\right)$ including $61.7 \%$ macrophages, $12.2 \%$ neutrophils, $8.2 \%$ lymphocytes, and $18.1 \%$ eosinophils. The CD4/CD8 ratio of lymphocyte subsets was 0.39 . The macrophage count included multinucleated giant cells (MGC), with a MGC/alveolar macrophage ratio of $8.3 \%$. The MGC showed their cannibalistic features in that their cytoplasm contained engulfed inflammatory cells.

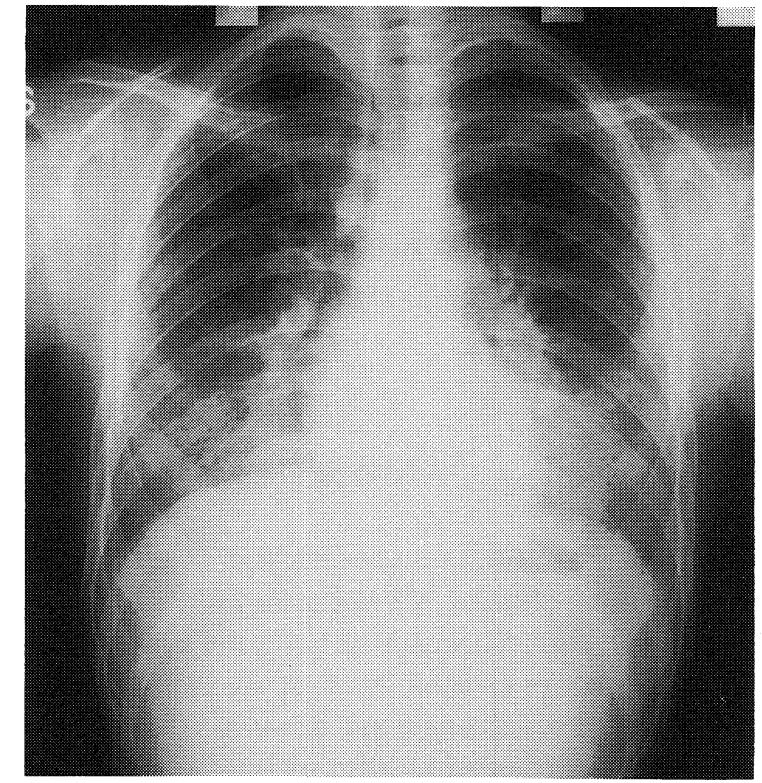

Figure 1. Chest radiograph reveals bilateral micronodular infiltrates with basilar predominance.
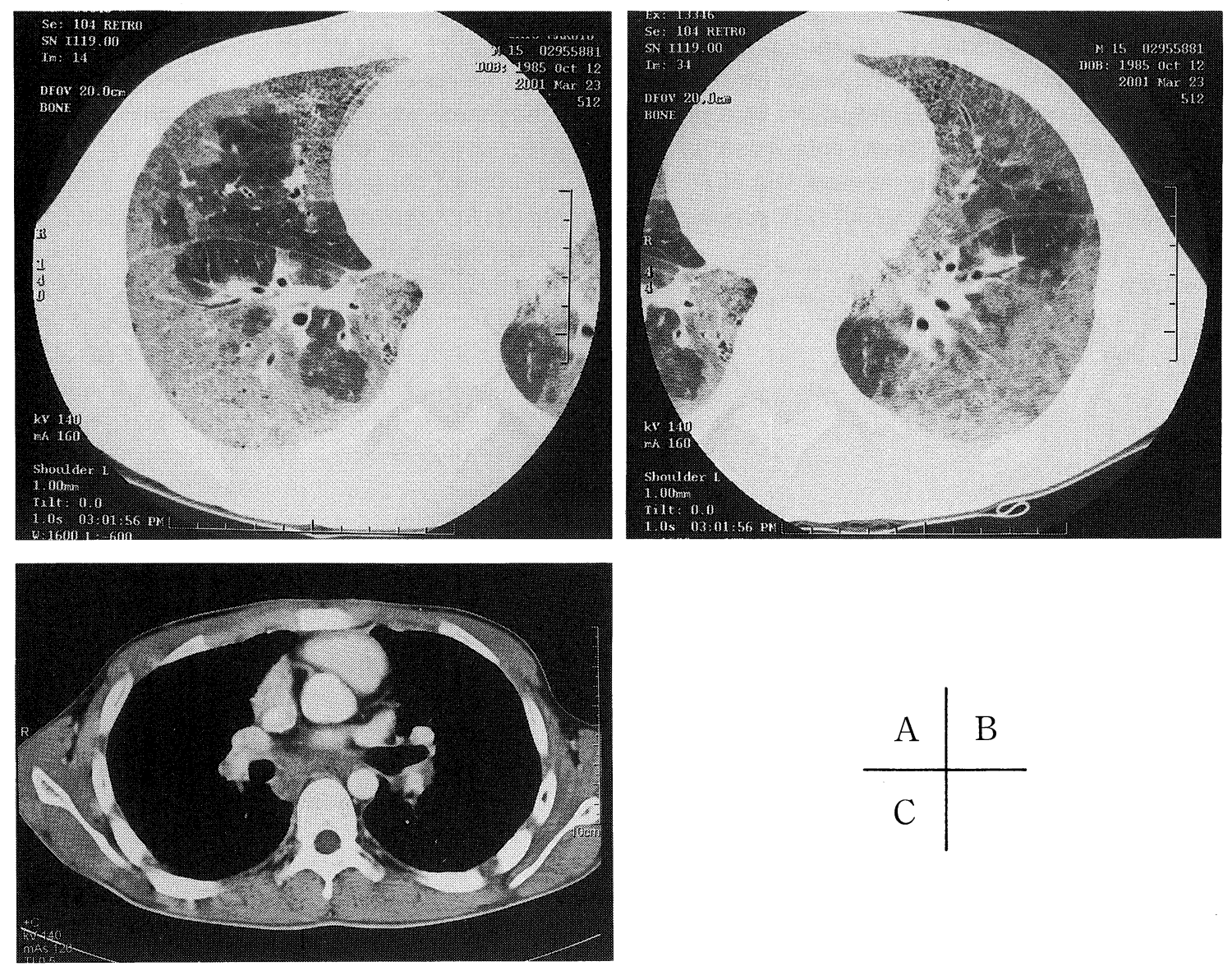

Figure 2. (A and B): Chest computed tomographic (CT) scans show diffuse ground-glass opacity in both lungs with basilar predominance. (C): Mediastinal lymph node swelling. 


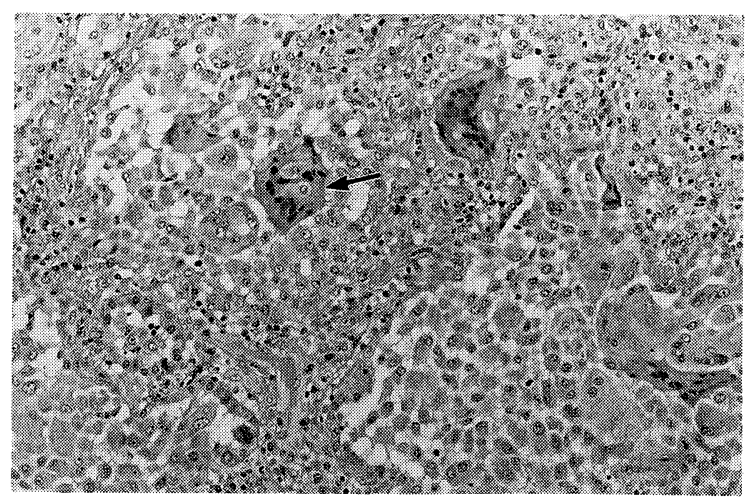

A

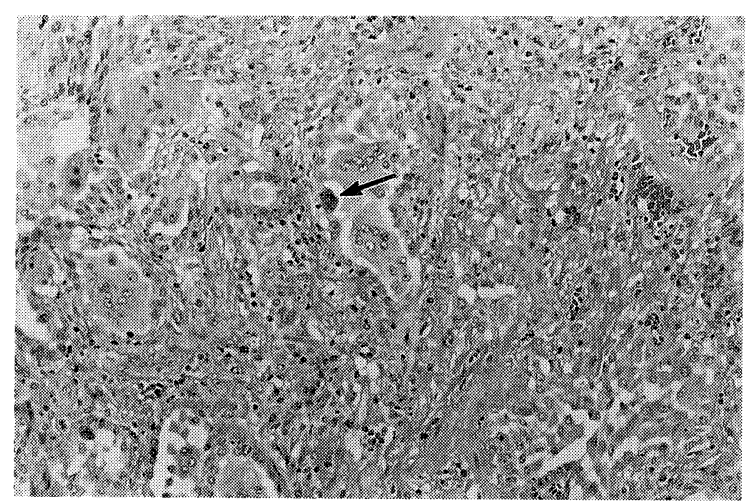

$\mathrm{B}$

Figure 3. Histopathological findings of a lung biopsy specimen obtained by video-assisted thoracoscopy. A) Alveolar macrophages fill most of the alveolar lumina. There are also many multinucleated giant cells. Note that most giant cells contain other cells such as macrophages (arrow) and neutrophils. B) Alveolar lumina are covered by cuboidal reactive pneumocytes with occasional multinucleated cell formation (arrow). Note also the stromal widening by fibrosis, edema and inflammatory cell infiltration (HE stain, $\times 180$ ).

To establish a definite diagnosis, lung biopsy was performed from $\mathrm{S}^{5}$ of the left lung by video-assisted thoracoscopic surgery (VATS). Pathological diagnosis was made as GIP, based on the accumulation of alveolar macrophages in the alveolar lumina and the presence of many multinucleated giant cells. The giant cells frequently contained engulfed cells such as macrophages and neutrophils. Alveolar lumina were covered by cuboidal reactive pneumocytes with occasional multinucleated cell formation. In addition, stromal widening by fibrosis, edema and inflammatory cell infiltration was evident. These pathologic changes were diffuse and monotonous. Histologic change seen in the alveoli near the terminal airway and those in peri-acinar location showed no difference. There was no temporal heterogeneity that is typically seen in UIP (Fig. 3). Analysis of inorganic elements by plasma optical emission mass spectrometer (POEMS 3, Thermo-Jarrell Ash Co., USA) demonstrated neither cobalt nor tungsten in the frozen specimen. We also could not detect those elements by transmission electron microscopy (JEM-1210, JEOL. Tokyo, Japan) and energy dispersive X-ray analysis (DX-4, EDAX. New Jersey, USA). For the analysis, ten parts of tissues $(1 \times 1 \times 1 \mathrm{~mm}$ for each) were taken from the paraffin embedded specimen. Mounted paraffin sections were de-waxed in xylene and embedded in epoxy resin with or without postfixation in $1 \%$ osmium tetroxide. Ultrathin sections (70 to $80 \mathrm{~nm}$ ), mounted on nylon grids, were examined.

Immediately after VATS, the clinical condition and chest radiograph deteriorated. Accordingly, the patient was treated with a high dose of methylprednisolone (1 g/day intravenously for three days) followed by oral prednisolone ( $40 \mathrm{mg} /$ day), which was then tapered off gradually. Three months after therapy, his clinical condition gradually improved, and chest HRCT scans showed disappearance of abnormalities (Fig. 4).

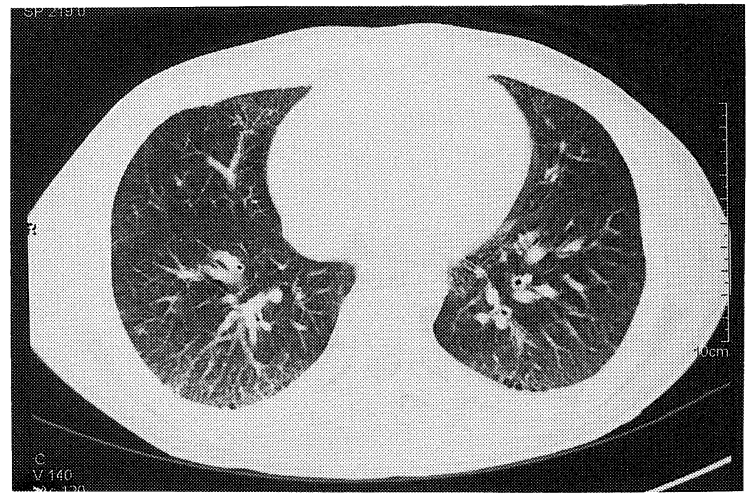

Figure 4. Chest CT findings three months after corticosteroid therapy, showing remarkable improvement.

The levels of serum KL-6, SP-D and SP-A gradually returned to within the normal range.

\section{Discussion}

Recent studies suggest that the majority of cases of GIP are caused by exposure to cobalt or tungsten carbide as components of hard metals $(2,3)$. It is, therefore, considered as a form of pneumoconiosis and currently the terms of hard metal lung disease or hard-metal pneumoconiosis is preferred (2-4). Animal experiments have demonstrated the induction of interstitial lung disease by high doses of powdered cobalt but not by tungsten carbide, titanium, or tuntalum (5-7). Thus it appears that cobalt is the offending metal, but the mechanism by which cobalt/tungsten produce interstitial pneumonia is still 
controversial, although there is increasing evidence for an immune-mediated etiology $(8,9)$. This includes the finding of specific anti-cobalt immunoglobulin (Ig) E and a positive cobalt intradermal test in patients with cobalt-associated asthma (10) as well as the presence of cobalt eczema and a positive patch test $(11,12)$ and positive lymphocyte stimulation test in some patients with interstitial pneumonia (13). There is also a report of GIP treated by lung transplantation with recurrence of the original disease in the transplanted organ in the absence of exposure to cobalt and tungsten after transplantation (14). Thus, it is highly suggestive of an autoimmune mechanism for this occupational disease.

The present patient was a junior high school student, and had almost no chance for exposure to hard metals in his daily life. In addition, neither cobalt nor tungsten was detected in the biopsied lung specimen. We also analyzed water samples from his surroundings for the possible presence of hard metals, but neither cobalt nor tungsten was detected. Chest radiographs taken for all members of the family were clear and showed no abnormalities, in concordance with the asymptomatic state. Thus, in this young case the cause-and-effect relationship is not certain, although we could not exclude possible exposure to hard metals in very small amounts through his parents. Assuming the latter, this case suggests the importance of immunological response to hard metals rather than dose-dependent response in GIP. It should be emphasized that the lymphocyte stimulation test and patch tests using cobalt and tungsten were negative in the present patient, in contrast to some case reports with positive results of these tests (11-13). On the other hand, the increased number of eosinophils in BAL fluid in our case might also suggest an allergic reaction.

We reviewed eleven cases of GIP reported in Japan including the present case (Table 1) $(12,13,15-21)$. Almost all cases were middle aged; the average age at onset was $46.18 \pm 14.98$ years (range, 15-70) (12-21). Onset under 20 years old is rare; to our knowledge, this is the youngest case of GIP reported in the world. Eight of eleven cases were male patients $(12,13$, 15-21). Occupational histories included grinding edged tools,

Table 1-1. Clinical Profiles of Eleven Patients with GIP Reported in Japan

\begin{tabular}{|c|c|c|c|c|c|c|c|c|c|}
\hline $\begin{array}{l}\text { No. of } \\
\text { patients }\end{array}$ & $\begin{array}{l}\text { Year/ } \\
\text { Authors }\end{array}$ & $\begin{array}{l}\text { Age, } \\
\text { sex }\end{array}$ & Symptoms & $\begin{array}{l}\text { Years of } \\
\text { exposure to } \\
\text { hard metal }\end{array}$ & Occupation & $\begin{array}{l}\text { Elemental } \\
\text { analysis of } \\
\text { the biopsied } \\
\text { lung/Method }\end{array}$ & $\begin{array}{l}\text { Pulmọnary } \\
\text { function tests }\end{array}$ & $\begin{array}{c}\text { Lymphocyte } \\
\text { stimulation test/ } \\
\text { Patch test }\end{array}$ & ${ }^{*} \mathrm{CD} 4 / \mathrm{CD} 8$ \\
\hline 1 & $\begin{array}{c}\text { 1976/Nomura } \\
\text { (15) }\end{array}$ & $\begin{array}{l}43, \\
F\end{array}$ & $\begin{array}{c}\text { dyspnea on exertion, } \\
\text { fever up }\end{array}$ & 2 & $\begin{array}{c}\text { grinder of edged } \\
\text { tool }\end{array}$ & ND & ND & ND & ND \\
\hline 2 & $\begin{array}{c}\text { 1980/Hanawa } \\
(16)\end{array}$ & $\begin{array}{l}50 \\
\mathrm{M}\end{array}$ & $\begin{array}{l}\text { dyspnea on exertion, } \\
\text { cough, fever up }\end{array}$ & 2 & grinder of saw & ND & $\mathrm{R}$ & ND & ND \\
\hline 3 & $\begin{array}{c}\text { 1986/Wada } \\
\text { (17) }\end{array}$ & $\begin{array}{l}43, \\
M\end{array}$ & $\begin{array}{c}\text { dyspnea on exertion, } \\
\text { cough }\end{array}$ & $1-2$ & $\begin{array}{l}\text { production of hard } \\
\text { metal }\end{array}$ & W/EDXM & $\mathrm{R}, \mathrm{D}$ & ND & ND \\
\hline 4 & $\begin{array}{c}\text { 1989/Miyazaki } \\
\text { (18) }\end{array}$ & $\begin{array}{l}61 \\
M\end{array}$ & $\begin{array}{l}\text { dyspnea on exertion, } \\
\text { cough, fever up }\end{array}$ & $\begin{array}{c}\text { not } \\
\text { certain }\end{array}$ & office worker & ND & $\mathrm{R}, \mathrm{D}$ & ND & ND \\
\hline 5 & $\begin{array}{l}\text { 1992/Oki } \\
(12)\end{array}$ & $\begin{array}{l}70 \\
\mathrm{M}\end{array}$ & dry cough & 6 & polisher of drills & $\begin{array}{c}\text { W, } \\
\text { no } \mathrm{Co} / \mathrm{EDXM}\end{array}$ & $\mathrm{R}$ & see 1) & 0.73 \\
\hline 6 & $\begin{array}{c}\text { 1995/Seike } \\
(19)\end{array}$ & $\begin{array}{l}48 \\
M\end{array}$ & dyspnea on exertion & $>10$ & $\begin{array}{l}\text { grinder of edged } \\
\text { tool }\end{array}$ & W/EDXM & ND & ND & ND \\
\hline 7 & $\begin{array}{l}\text { 1999/Kinoshita } \\
\text { (20) }\end{array}$ & $\begin{array}{c}44, \\
F\end{array}$ & $\begin{array}{c}\text { cough, dyspnea on } \\
\text { exertion }\end{array}$ & 6 & $\begin{array}{l}\text { polisher of hard } \\
\text { metal tools }\end{array}$ & $\begin{array}{c}\text { no W, } \\
\text { no } \mathrm{Co} / \mathrm{EDXM}\end{array}$ & $\mathrm{D}$ & ND & 0.4 \\
\hline 8 & $\begin{array}{l}\text { 1999/Kinoshita } \\
\text { (20) }\end{array}$ & $\begin{array}{l}28 \\
\mathrm{M}\end{array}$ & cough & 9 & $\begin{array}{l}\text { polisher of hard } \\
\text { metal tools }\end{array}$ & W/EDXM & $\mathrm{R}, \mathrm{O}$ & ND & 0.4 \\
\hline 9 & $\begin{array}{c}\text { 2000/Ishida } \\
\text { (21) }\end{array}$ & $\begin{array}{l}50 \\
\mathrm{M}\end{array}$ & $\begin{array}{c}\text { dyspnea on exertion, } \\
\text { productive cough }\end{array}$ & 14 & $\begin{array}{c}\text { office worker } \\
\text { (grinder of edged tool) }\end{array}$ & $\mathrm{W}, \mathrm{Co} / \mathrm{EDXM}$ & $\mathrm{R}$ & ND/see 2) & ND \\
\hline 10 & $\begin{array}{c}\text { 2001/Kusaka } \\
\text { (13) }\end{array}$ & $\begin{array}{l}56, \\
M\end{array}$ & ND & ND & dental technician & ND & ND & see 3)/ND & ND \\
\hline 11 & 2001/Prsent case & $\begin{array}{l}15 \\
M\end{array}$ & $\begin{array}{c}\text { dyspnea on exertion, } \\
\text { cough }\end{array}$ & $\begin{array}{c}\text { not } \\
\text { certain }\end{array}$ & student & see 5) & $\mathrm{R}, \mathrm{D}$ & see 4) & 0.39 \\
\hline
\end{tabular}

ND: not described, W: tungsten, EDXM: energy dispersion X-ray microanalysis, R: restrictive ventilatory defect, D: diffusion impairment, O: obstructive impairment, *CD4/CD8: CD4/CD8 ratio of lymphocytes in the BAL fluid. 1): this case showed negative lymphocyte stimulation test with cobalt and tungsten, positive patch test with cobalt, negative patch test with tungsten. 2): this case showed positive patch test with cobalt, negative patch test with tungsten. 3): this case showed positive lymphocyte stimulation test with cobalt. 4): this case showed negative lymphocyte stimulation test and patch test with cobalt and tungsten. 5): Elemental analysis of inorganic elements by plasma optical emission mass spectrometer (POEMS 3, Thermo-Jarrell Ash Co., USA) demonstrated neither cobalt nor tungsten in the biopsy specimen. We also failed to detect those elements by scanning electron microscopy or energy dispersive X-ray analysis. 


\section{GIP in a 15-year-old Boy}

saw, and drills by using hard metal-reinforced disks, or polishing hard metals by using diamonds (seven cases) $(12,15,16$, 19-21), production of hard metal (one case) (17), and dental technician (one case) (13). In these cases, the risk of inhalation of hard metal dusts was evident. Although analysis of inorganic elements in biopsied lung specimen was performed on 7 of 11 cases, cobalt was detected in only 1 case, whereas tungsten was detected in 5 cases $(12,17,19-21)$. This may be due to the high solubility of cobalt in plasma. In our case, although analysis of the biopsied lung tissue for cobalt and tungsten was negative, we could not exclude the possible elution of these elements through the process of fixation of lung tissue. In addition to our case, only one other patient had neither a past history of exposure to hard metals nor to organic dusts (18). Pulmonary function studies showed restrictive changes in seven cases, and diffusion impairment in four $(12,16-18,20,21)$.
Chest radiographic findings of GIP ranged from reticular shadows to reticulonodular infiltrates with end-stage interstitial fibrosis $(12,15-21)$ in both lung fields. Basilar predominance was seen in seven cases $(12,15,16,18,20)$. The BAL of four cases, including the present case, showed a low CD4/CD8 T cell ratio $(12,20)$. Very large numbers of MGC in BAL fluid were noted, with MGC/alveolar macrophage ratio of $8.3 \%$ in the present case. Multinucleated giant cells are usually limited in BAL fluid from patients with various interstitial lung diseases and healthy individuals, ranging from $0.25 \%$ to $2.5 \%$ of all alveolar macrophages $(20,22)$. The presence of bizarre MGC might be useful for diagnosis of GIP, especially when cannibalistic features accompany a history of hard metal exposure. Although definite diagnosis of GIP was made only by performing transbronchial lung biopsy (TBLB) in 3 cases of 10 (12, $18,20)$, in the present patient we could not make a definite

Table 1-2. Clinical Profiles of Eleven Patients with GIP Reported in Japan

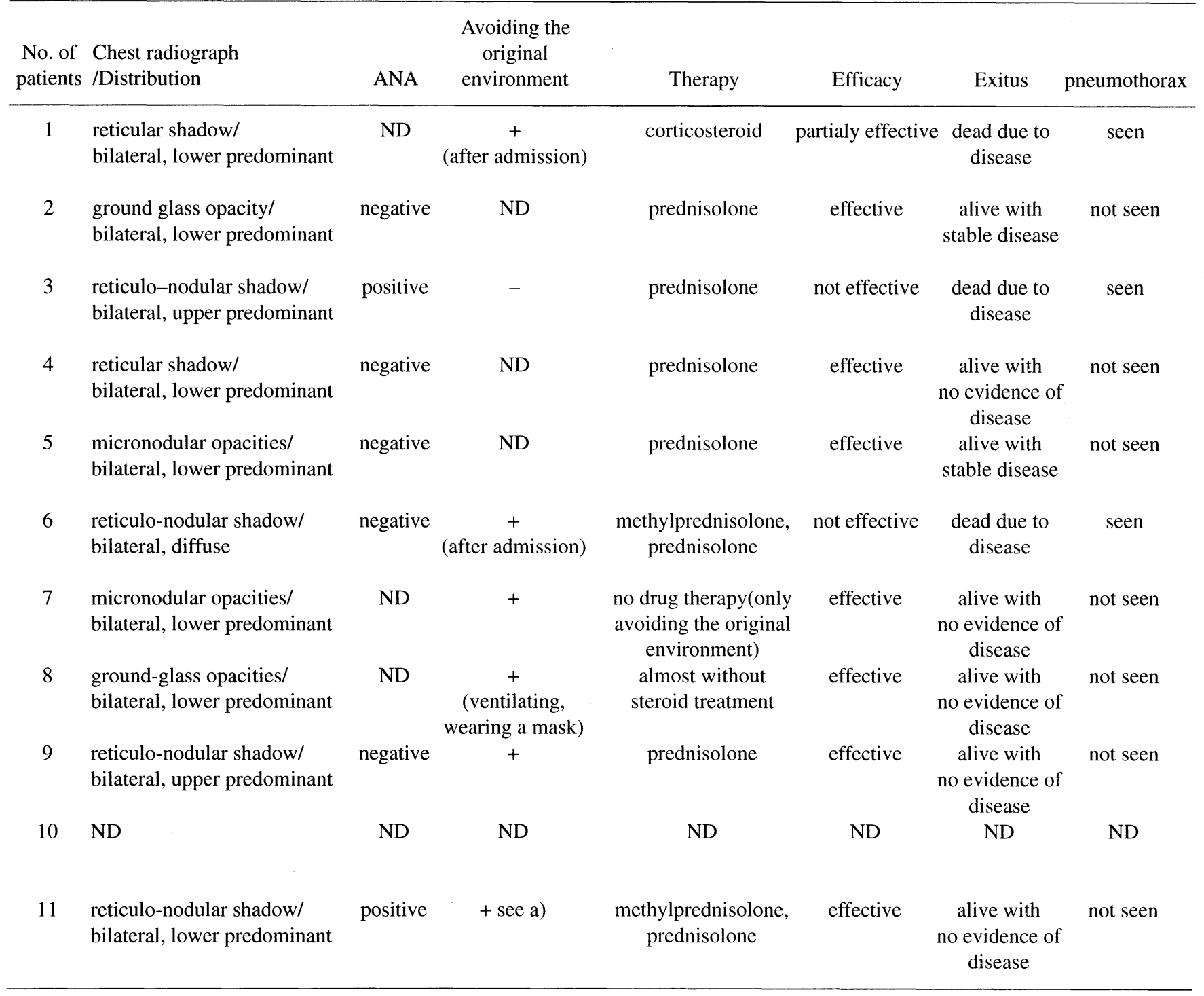

ND: not described. a) In this case, patient returned to the original environment after discharging from the hospital. 
diagnosis by TBLB only. It may raise the point of the difficulty in distinguishing GIP from DIP, respiratory bronchiolitis-associated interstitial lung disease (RB-ILD) and other lung diseases only by TBLB. Therefore, it is preferable that VATS is performed, especially when exposure to hard metal is not evident. Nine patients were treated with steroids $(12,15-21)$. Although seven patients improved, three died of the disease (12, 15-21). One case improved only after avoiding the original environment (20). Since GIP seems to be caused by hard metal exposure, avoiding exposure is thought to be essential treatment. However, previous studies showed no relationship between onset, prognosis and duration of hard metal exposure $(12,15-17,19-21)$. Pneumothorax was seen in all deceased cases $(15,17,19)$, probably due to end-stage pulmonary fibrosis. In these cases, treatment with steroids was ineffective. Consequently, physicians should try to determine the causative factors in patients with respiratory symptoms, in workers exposed to hard metals, and even in their family members including children.

Acknowledgements: The authors thank Dr. Masanori Kitaichi, Department of Laboratory Medicine, Kyoto University Hospital, for his advice in pathological diagnosis, and Dr. Atsuhiro Nakano, National Institute for Minamata Disease, for elemental analysis of the biopsied lung.

\section{References}

1) Liebow AA, Smith DE. New concepts and entities in pulmonary disease. in: The Lung, (Liebow A.A., Smith DE., Eds), 332-365, 1968.

2) Abraham JL. Lung pathology in 22 cases of giant cell interstitial pneumonia (GIP) suggests GIP is pathognomonic of cobalt (hard metal) disease. Chest 91: 312, 1987 Abstract.

3) Ohori NP, Sciurba FC, Owens GR, Hodgson MJ, Yousem SA. Giant-cell interstitial pneumonia and hard-metal pneumoconiosis. A clinicopathologic study of four cases and review of the literature. Am J Surg Pathol 13: $581-587,1989$.

4) Colby TV, Carrington CB. Interstitial lung disease. in: Pathology of the Lung. Thurbeck WM, Churg AM, Eds. Thieme Medical Publishers, New York, 589-737, 1995.

5) Delahant $\mathrm{AB}$. An experimental study of the effects of rare metals on animal lungs. AMA Arch Industr Health 12: 116-120, 1955.

6) Schepers GWH. The biological action of particulate cobalt metal. AMA Arch Industr Health 12: 127-133, 1955.
7) Schepers GWH. The biological action of tungsten carbide and cobalt. AMA Arch Industr Health 12: 140-146, 1955.

8) Demedts M, Ceuppens JL. Respiratory diseases from hard metal or cobalt exposure: solving the enigma. Chest 95: 2-3, 1989 (editorial).

9) Shirakawa T, Kusaka Y, Fujimura N, et al. Occupational asthma from cobalt sensitivity in workers exposed to hard metal dust. Chest 95: 29 37, 1989.

10) Abraham JL, Burnett BR. Quantitative analysis of inorganic particulate burden in situ in tissue sections. Scanning Electron Microsc 2: 681-696, 1983.

11) Sjogren I, Hillerdal G, Andersson A, Zetterstrom O. Hard metal lung disease: importance of cobalt in coolants. Thorax 35: 653-659, 1980.

12) Oki K, Arakawa Y, Sugita H, Sakamoto Y, Kawabata Y. A case of hard metal disease showing increase and activation of lymphocytes in bronchoalveolar lavage fluid. Allergy no rinshou 12: 971-975, 1992 (in Japanese).

13) Kusaka Y, Sato K, Suganuma N, Hosoda Y. Metal-induced lung disease: Lessons from Japan's experience. J Occup Health 43: 1-23, 2001.

14) Frost AE, Keller CA, Brown RW, et al. Giant Cell Interstitial Pneumonitis. Disease Recurrence in the Transplanted Lung. Am Rev Respir Dis 148: 1401-1404, 1993.

15) Nomura T, Hirabayashi N, Nause T, Ryuge K, Ushizima H, Satake T. An autopsy case of giant cell interstitial pneumonia (GIP). Nippon Kyoubu Shikkan Gakkai Zasshi 14: 270-276, 1976 (in Japanese, Abstract in English).

16) Hanawa $M$, Narita $M$, Mabuchi $T$, et al. A case of giant cell interstitial pneumonia (GIP) successfully treated with corticosteroid. Nikkyo 4: $341-$ 345, 1980 (in Japanese, Abstract in English).

17) Wada M, Nishikawa $H$, Katagiri $S$, et al. A case report of the hard metal lung with giant cell interstitial pneumonia. Nippon Kyoubu Shikkan Gakkai Zasshi 24: 703-709, 1986 (in Japanese, Abstract in English).

18) Miyazaki N, Kido M, Kajiki A, Morimoto Y. A Case of giant cell interstitial pneumonia. Sangyo Ika Daigaku Zasshi 11: 63-67, 1989.

19) Seike M, Usuki J, Uematsu K, et al. Giant cell interstitial pneumonia in a metal grinder with an abnormally high level of serum CA19-9. Nippon Kyoubu Shikkan Gakkai Zasshi 33: 894-899, 1995 (in Japanese, Abstract in English).

20) Kinoshita M, Sueyasu $Y$, Watanabe H, et al. Giant cell interstitial pneumonia in two hard metal workers: The role of bronchoalveolar lavage in diagnosis. Respirology 4: 263-266, 1999.

21) Ishida T, Sato M, Terada M, Suzuki E, Shimojo H, Kobayashi M. A case of hard metal pneumoconiosis in an office worker of drill grinding plant who was treated as diffuse panbronchiolitis. Ther Res 21: 1871-1875, 2000 (in Japanese).

22) Davison AG, Haslam PL, Corrin B, et al. Interstitial lung disease and asthma in hard-metal workers: Bronchoalveolar lavage, ultrastructural, and analytical findings and results of bronchial provocation test. Thorax 38: 119-128, 1983. 